\title{
Development Modelling: The State of the Art
}

\author{
JAN TINBERGEN*
}

\begin{abstract}
After a brief historical survey starting around 1930, the article discusses some of the main new concepts used in development models. Thus, the Domar-Harrod principle, planning in stages, input-output, and two-gap models are discussed. From national models we have now attained a point of world models.

The newest developments are characterized by the introduction of income distribution variables, the informal sector, appropriate technologies and environmental variables. New uses made of models recognize the existence of more than one policy maker, or alternative groups in power as well as "interactive multiple goal planning".
\end{abstract}

\section{HISTORICAL}

Development policies may be considered a component-and a very important one at that-of socio-economic policies generally. Accordingly, the roots of development planning have to be looked for in the first attempts to conduct socioeconomic policies in a planned way. Two branches stand out; central planning as developed in the Soviet Union from the late 1920s onward, and indicative macroplanning, as elaborated in some Westem countries. Of course, there are large differences between the two approaches. Soviet planning was seen as obligatory (as distinct from indicative), and it (as distinct from macro planning) dealt with an enormous number of details. For quite some time, moreover, the use of mathematical models was not considered appropriate in the Soviet Union. In this article I propose to deal with socio-economic policy preparation with the aid of econometrically tested models. The first attempts originated in the Netherlands in 1936, when I, assisted by B. G. F. Buys, set up a simple macro-model in order to formulate a policy for that period, in the aftermath of the great depression [20].

During World War II, J. E. Meade and collaborators in the British "Cabinet Offices" made related studies directed at the solution of war finance problems.

After World War II, various forms of indicative planning-with a varying degree of compulsion-developed in Western countries. In the USA, the Council of Economic Advisors was established, but the main emphasis of its activities was

*The author, a Nobel Laureate (Economics), is Professor Emeritus at the Centre for Development Planning, the Erasmus University, Rotterdam (Holland). 
only on the framework of government policies. Model-building was taken up by university economists, especially by Lawrence R. Klein and A. S. Goldberger $[10 ; 11]$, and later organized by a large group under the auspices of the Brookings Institution $[7 ; 8]$.

In France, a form of indicative planning was developed much closer to compulsory planning, and institutionalized in the Commissariat au Plan, successively directed by such well-known men as Monnet, Masse, Hirsch, Ripert and others. As in the Soviet Union, Five-Year Plans constituted the formal framework for the scientific set-up.

In Norway, indicative planning started soon after the end of World War II. In the beginning, national budgeting was the point of focus. At an early stage, the elements of macro-economics from Keynes's work and input-output technique were added and from 1960 on models were elaborated under the name of Modis, which united these various features in a highly sophisticated form [2]. Work on the successive models was done by a large group of both university and civil service economists, educated and guided for years by Ragnar Frisch, who, in later years, increasingly concentrated on planning models for developing countries, especially for Egypt and India.

In the Netherlands, indicative planning started right after World War II, but models were introduced a few years later only. Starting with relatively simple macromodels, similar to the 1936 model, the Bureau developed a succession of increasingly sophisticated models. Great care was given to the elaboration of a vintage model,i.e. a model in which each year equipment of a more modern type is introduced, with its own number of workers per unit of equipment. For several years, no distinction was made between the various sectors of the economy, but recently a number of sectors have been introduced as a new experiment (cf. [6]).

Step by step, most of the Western European countries introduced planning agencies, under varying names and using different methods. Britain stopped the war-time planning, and, after a number of years, only tried to make a new start, influenced by the French system. This, too, was stopped in favour of a discussion on the "crisis of planning". Belgium introduced an official planning bureau. Sweden, interestingly, did not introduce more than an official business-cycle policy bureau, but the organization of industrialists introduced the use of a sophisticated model. Finally, the biggest university model-building institute turned out to be the Belgian DULBEA (The Free University of Brussels's Department of Applied Economics), where models of many kinds were built. One particular operation carried out in Brussels was the linking of a number of models (cf. [22]).

\section{MODELS FOR DEVELOPMENT PLANNING: EARLY PHASES}

Of course, there is no clear line of demarcation between the first group of models as sketched out briefly in the preceding section of this paper and the fullfledged development models directed at longer-term objectives. Our examples already illustrated a number of inter-connected research activities and some of their applications.

Among the developing countries, India was probably the first to introduce its own planning system, guided by P. C. Mahalanobis, who was impressed very much by the Soviet accomplishments, and took over the habit of drawing up five-year plans. Mahalanobis was the first to introduce the so-called specific capital goods, differentiating between capital goods needed to produce consumer goods and capital goods to produce capital goods. The main use made by him of this concept is to show that, to put it simply, initial restraint on consumption may later bring higher levels of wellbeing than in the absence of the initial restraint.

Understandably, in developing countries, interest was more concentrated on long-term movements of the economy than in developed countries where short-term movements (especially cyclical) and speculative operations evoked more interest. For any economy, however, short-term fluctuations can not be fully neglected. In developing economies, they probably are to a larger extent the consequences of crop variations and hence almost random. So, short-term economic models also became a subject for systematic research, as shown by Narasimham [15].

With an increasing number of former colonies becoming independent, at least formally, the formulation of development policies as part of a government's tasks spread. This was enhanced by institutions, such as the World Bank Group and the International Monetary Fund, which needed a basis of evaluation of the loans extended to developing countries. International co-operation also began to be more institutionalized, as shown by the solemn proclamation, in 1961, of the "Development Decade", later rebaptized as the First D. D. (D. D. I).

In view of the increasing practical applications of what erstwhile were principles only, such as the "Domar-Harrod principle", a number of more concrete and simplifying techniques were proposed, discussed and applied. One of these was planning in stages, where initially three levels were distinguished: the macro, the middle (or meso), and the micro levels. Macro calculations used national totals, such as national income or product, investments, consumption, imports and exports. The next stage referred to sectors or branches of activity in its "functional" version, or provinces in its "geographical" version, which, in the case of a federated nation, might be states. The micro-level of the functional version would be single projects (sometimes enterprises), the subject matter of loan negotiations. (A separate source of information usually resulted from such negotiations.) In the geographical version, either cities or homogeneous regions, possibly river valleys, entered the scene.

Among the sectors, some might receive special attention; for instance, education or educational subsectors. Alternatively, public and private, or formal and informal sectors, had to be kept apart.

A technique that found widespread application is known as input-output analysis, originating from previous concepts of production of goods by goods (Sraffa) and the core also of the Soviet planning system, even if not infrequently in simplified 
ways, with the emphasis on the "material balances". A refinement of conventional input-output analysis was obtained by a distinction between tradables and nontradables and got the name of semi-input-output analysis (cf. [12]).

Another useful tool of analysis proved to be the two-gap concept. A nation, when looked at as a whole, may be in disequilibrium in the sense that either its savings fall short of the investmets it wants to finance or its exports fall short of the imports it wants to finance. The former gap is indicated as the savings gap, the latter as the trade gap (where trade implies invisibles). In fact, and "ex post" (looking at the figures of past time units), the two are identical and in that sense there is no point in using two words. But, estimated in advance, "ex ante", the two may be different and one appears larger than the other. It is then sometimes called "dominant" and this state of affairs may be an indication of the measures that need to be taken first. The variables that are the subject of such measures are called "adjustors". Their use, and the adjustment process, may be either automatic (part of the "free forces of society") or policy-induced. If more than one adjustor exists, we may even have one or more "degrees of freedom". Several authors have used the tool just mentioned in order to arrive at policy recommendations or even a range of possible policies, where the policy-maker has a choice. An excellent survey of the practice of and experience with planning has been given by Waterston et al. [23].

A last remark to be made in this section is on international models. These became increasingly necessary as a consequence of the task created by the institution of the United Nations Development Planning Committee. This committee came into being as a consequence of the concern, around 1965, in the developing countries that the Development Decade's objectives were not attained. On behalf of the committee's discussions, the UN Secretariat prepared a world model, largely inspired by J. L. Mosak, but unfortunately never published it. In all probability, it was the first of its kind. More recently, Leontief et al. [13] made an impressive attempt at constructing various alternatives of a world model.

\section{ASPECTS UNDER DEBATE AROUND THE YEAR 1980: THE SITUATION}

After this brief survey of some historical developments and the early phases of development planning, we propose to discuss the present state of the art of development planning. For its understanding, we have to recall the recent changes in the world situation and some of the reactions to them. In a general way, actual developments in the last two decades have brought disappointment and frustration to all concerned. True, the rate of growth of total production in a part of the Third World has not been low in comparison to what, before 1945, industrialized countries had attained. Contrary to original hopes, these grown incomes had not (with a few exceptions), "trickled down" to the poorer part of even the successful countries. Also, the countries with the lowest per capita income had hardly participated in whatever successes there had been. So, the number of those who could not even satisfy their most basic needs had increased. An important part of the explanation is to be sought in the accelerated population growth: new medical attacks on diseases had brought some more health but also more poverty. Lives had been saved that were hardly worth living.

Another part of the explanation was the divergence of interests between the ruling groups and the mass of the population. Governments often represented the interests of big land owners and not those of the increasing number of landless peasants or holders of shrinking lots. The land couldn't offer-or the land owners didn't offerjobs for all and so there started a flow of migrants to the cities in search of employment there, without much success. The well-known slum areas now surround all cities. Another migrant flow came into being, this time to the industrialized countries, where migrants were prepared to do the hard and dirty work at wages for which the indigenous labour force was no longer prepared to take these jobs.

Apart from the situation in the developing countries, the state of affairs in the industrialized world showed an unexpected change. After two decades of remarkably quick development, a turning point appeared, of which one of the earliest symptoms was the delinking of the dollar from gold. In 1971, that key currency became floating and with it a chaotic monetary situation started which soon depreciated the dollar to about one-half of its former value in terms of the stronger currencies (Deutsche Mark and Yen). A recession set in, with the until-then-unheard-of "Stagflation", i.e. stagnation in production and employment with inflation, characterized by rising, instead of falling, prices. In 1973, another new phenomenon complicated the situation. As a first example of the action taken by a group of the Third World countries, the Organization of Petroleum Exporting Countries (OPEC) acted as a cartel and raised the price of oil by a substantial amount. This reinforced the recession, intensified inflation and added considerable difficulties to the non-oilexporting countries of the Third World. As a consequence of further price rises in the West, partly due also to further wage rises, the oil-exporting countries became aware of the dwindling value of the payments they received for their oil. To date (1980), the stagflation has persisted. In the meantime, it has been understood that the higher oil prices were more in line with the relative scarcity of this exhaustible mineral than the low prices that had prevailed before.

Gradually, the whole of the Third World started to understand that selfreliance was the answer to the indifference shown by the industrialized countries for development co-operation. Those among the international organizations in which developing countries had been leading - UNCTAD and UNIDO - formulated proposals on trade, commodity agreements and industrialization, which, in a Special Session of the General Assembly of the U. N., were integrated into a many-faceted proclamation of a New International Economic Order. 


\section{ASPECTS UNDER DEBATE AROUND THE YEAR 1980:} THE MODELS

With the situation as sketched in Section 3 as a background, let us now discuss how the experiences of the past decades and the new tasks as now understood have their impact on development planning and the models to be used for it. We will discuss this impact under two main headings: (a) the additional variables that must enter into our models, and (b) the new use to be made of planning models.

The additional variables needed for our models will be discussed in succession, without a claim to completeness. To begin with, more social variables are need ed and a first example is of figures on income distribution. Although accurate data are hard to get, crude approximations have been estimated for up to sixty developing countries. A crude distinction into quintiles of income distribution will aiready be useful; for links have to be made with other variables in order to integrate them into the model. An interesting example is given by Bornschier [4] in a sociological model, comparing up to 72 countries in a cross-country study. Another very complex study for one country, Korea, shows what can be undertaken in the socioeconomic field for a country known for its wealth of data [1]. A host of other social data are being collected under the general name of social indicators, which claim an important position in the welfare concept [14;19].

Another extension of the number of the needed variables relates to the "informal sector". Depending on the type of information needed, some of it will be already part of the official statistics, as handicraft and other small-scale business. Sample surveys are the best known tool to obtain data on the informal sector, and in some countries, e.g. India, there is a vast wealth of them. Yet the general impression is that much remains to be done in this field. For a developed country, such as Britain, novel ideas have been formulated on both the household and the informal (partly illegal) sectors by Gershuny [9]

Of late, the discussion on appropriate technology has acquired much momentum. As a matter of course, most information has to come from single enterprises, and economists will have to co-operate with engineers. Path-breaking work has been done by Boon [3], a good deal under the auspices of E1 Colegio de Mexico, but also by Beyrard, and probably by many consulting engineering firms. Among the United Nations organizations, UNIDO and FAO are the most involved, but twice already a general conference on the subject of science and development (Geneva, 1963 and Vienna, 1979) was organized. The subject is so vast that each sector in each country required its own treatment. While there is much scope for the application of the principle of self-reliance in this field also, one world-wide problem looms large at the horizon of technology, namely the consequences of the introduction of microelectronic devices. Even though inertia will slow down real developments in comparison to those theoretically deduced from what the avant-garde performs, the need for case studies concerning previous generations of electronic devices is strong. In such case studies, important variables to be ascertained are the capital intensity of new processes and the elasticity of demand for their services. If the latter is high, which is by no means impossible, the threat to employment is less, of course, than if that elasticity is low. Some institutions in the field of banking have announced their expectation of no threat to employment, but opinions widely diverge. The impact on comparative costs in developed and developing countries has hardly been put on the agenda for discussion, but, as a matter of course, it should be included.

Some technologies will experience the impact of higher energy prices; these have made feasible, economically speaking, village-level activities such as biogas production [18].

Some of the important new variables which must be introduced into development models are of an environmental character. Among them may be the minimum surface under forests, i.e. the surface needed to avoid desertification. For an island such as Java, Indonesia's densely populated central island, this is now becoming a question of life and death; and transmigration of a part of Java's population to Sumatra is one of the most urgent activities to be organized at a much larger scale than heretofore.

This brings us to the category of non-measured variables which have now attracted the attention of model builders. We already mentioned variables concerning the informal sector, and could add the activities of self-reliance, by the "mobilization" of village populations, practised by the Institute of Cultural Affairs, located near Bombay, with affiliations all over the world. Econometricians are accustomed to entering non-measured variables into models with the aid of "proxies"; in a way, social indicators, discussed before, are such proxies for "happiness" or "utility" in economic jargon, the very aim of socio-economic policies.

Let us now turn to the (partly) new use that is going to be made of models.

Newer methodologies for use of econometric models nowadays abound (cf. [16]). One is needed to deal with a major fact of life, namely that policy-makers more often disagree than agree about their aims. Hence all sorts of compromising processes characterize development policies. The problem is more than a century old in economic science and was first tackled by the French economist Cournot in an attempt to describe the attitude of competitors who are few (representing a nearmonopoly situation). Several other new methods are tried out, all containing assumptions on how politicians "play their game" (cf. the Theory of Games, due to Von Neumann and Morgenstern [21]).

Another example of the new use made of models is due to Cohen [5]. His method consists in maintaining a sufficient number of degrees of freedom so as to alternatively use the model for maximizing welfare of different groups. Depending on the power shifts which may occur, another group's welfare function may be taken as maximum and so the effects of the power change can be studied.

Again, another way of using models is called interactive multiple-goal 
mize their objective function. They hardly know what an objective function means, but they do know which of the different situations they prefer. The planning process is given the shape of a dialogue between model-builders and policy-makers. The former show a feasible situation of the economy to the latter and ask them whether they want a change in any of the objective variables or targets. After the policy-maker has suggested a new value for that target, the model-handler tells him what other target has then to be changed (mostly in an unfavourable sense) and whether the change is worth the gain on the first target. Thus the dialogue finishes in a situation which, for the policy-maker, is the best attainable configuration.

\section{REFERENCES}

1. Adelman, J., and S. Robinson. Income Distribution Policies in Developing Countries. A Case Study of Korea. London: Oxford University Press. 1978. (Published for the World Bank)

2. Bjerkholt, O., and S. Longva. Modis IV, A Model for Economic Analysis and National Planning. Oslo: Central Bureau of Statistics for Norway. 1980. (Samfunns/konomiske Studier Nr. 43)

3. Boon, G. K. Technology and Sector Choice in Economic Development. Alphen a/d Rijn: Sijthoff and Nordhoff. 1978.

4. Bornschier, V. "Einkommensungleichheit innerhalb von Ländern in komparative Sicht”. Schweiz. Zeitschr. f. Soziologie. Vol. 4. 1978.

5. Cohen, S. I. Agrarian Structures and Agrarian Reforms. Leiden/Boston: Martinus Nijhoff. 1978.

6. Den Hartog, H., and H. S. Tjan. A Clay-Clay Vintage Model Approach for Sectors of Industries in the Netherlands. The Hague: Central Planning Bureau. 1979. (Occasional Paper No. 17)

7. Duesenberry, J. S., G. Fromm, L. R. Klein, and E. Kuh. The Brookings Quarterly Econometric Model of the United States. Amsterdam/Chicago: North Holland/Rand McNally \& Co. 1965.

8. Fromm, G., and L. R. Klein (eds.). The Brookings Model: Perspective and Recent Developments. Amsterdam/Oxford: North Holland/Elsevier. 1975.

9. Gershuny, J. I. Address to the Dutch Scientific Council of Government Policy. The Hague. 1979.

10. Klein, L. R. Economic Fluctuations in the United States. New York/London: Wiley/Chapman \& Hall Ltd. 1950.

11. Klein, L. R., and A. S. Goldberger. An Econometric Model of the United States, 1929-1952. Amsterdam: North Holland. 1955.

12. Kuyvenhoven, A. Planning with the Semi-Input-Output Method. Leiden/ Boston/London: Martinus Nijhoff. 1978.

13. Leontief, W., et al. The Future of the World Economy. New York: Oxford University Press. 1977.
14. Levy, S., and L. Guttman. "On the Multivariate Structure of Well-being", Social Indicators Research. Vol. 2. 1975.

15. Narasimham, N. V. A. A Short-Term Planning Model for India. Amsterdam: North Holland. 1965.

16. Nijkamp, P. Multidimensional Spatial Data and Decision Analysis. New York: Wiley. 1979.

17. Nijkamp, P., and J. Spronk. "Interactive Multiple Goal Programming”. Rotterdam: Centrum voor Bedrijfskundig Onderzoek, Erasmus University. 1978. (Report 7803/A)

18. Reddy, A. K. N., C. R. Prasad, and K. Krishna Prasad. "Bio-Gas Plants: Prospects, Problems and Tasks". Economic and Political Weekly. Vol. IX (Special Number). August 1974.

19. Scheer, Lore. Quality of Life. Vienna: Arbeitsgemeinschaft für Lebensniveauvergleiche. 1977.

20. Tinbergen, J. “An Economic Policy for 1936". Translated in his Selected Papers. Amsterdam : North Holland. 1959. pp. 37-84.

21. Von Neumann, J., and O. Morgenstern. Theory of Games and Economic Behavior. Princeton. N. J. (USA): Princeton University Press. 1944.

22. Waelbroeck, J. L. The Models of Project LINK. Amsterdam/New York/Oxford: North Holland. 1976.

23. Waterston, A., et al. Development Planning, Lessons of Experience. Baltimore, Md. (USA): The Johns Hopkins Press. 1965. 